\title{
PENERAPAN TEORI BELAJAR VAN HIELE UNTUK MENINGKATKAN AKTIVITAS DAN HASIL BELAJAR SISWA POKOK BAHASAN LUAS PERSEGI, PERSEGI PANJANG, DAN SEGITIGA
}

\author{
Farisia Pratiwi Umami ${ }^{1}$, Titik Sugiarti ${ }^{2}$, Fajar Surya Hutama ${ }^{3}$ \\ Universitas Negeri Jember
}

\begin{abstract}
The purpose of this study was to improve the activity and learning outcomes of fourth grade students of SDN Kepatihan 05 Jember through the application of van Hiele's learning theory. The type of research used is Classroom Action Research (CAR). This research was conducted in two cycles. Each action includes planning, implementation, observation, and reflection. Data collection techniques used were observation, interviews, learning outcomes tests, and documentation. The subjects of this study were all students of class IVA SDN Kepatihan 05 Jember, totaling 28 students. The results of this study indicate that the percentage of student learning activities has increased. In the first cycle the results were 56.29 percent with sufficient criteria, while in the second cycle it was 76.66 percent with good criteria. The average student learning outcomes also increase. In the first cycle the results were 55.74 with sufficient criteria, while in the second cycle 75.71 with good criteria. Based on the results of the study, it can be concluded that the application of van Hiele's learning theory can improve the activity and learning outcomes of class IVA students of SDN Kepatihan 05 Jember.
\end{abstract}

Keywords: van Hiele's theory. Learning activities, learning outcomes

\begin{abstract}
ABSTRAK
Tujuan dalam penelitian ini adalah untuk meningkatkan aktivitas dan hasil belajar siswa kelas IV SDN Kepatihan 05 Jember melalui penerapan teori belajar van Hiele. Jenis penelitian yang digunakan adalah Penelitian Tindakan Kelas (PTK). Penelitian ini dilaksanakan sebanyak dua siklus. Setiap tindakan meliputi perencanaan, pelaksanaan, pengamatan, dan refleksi. Teknik pengumpulan data yang digunakan adalah observasi, wawancara, tes hasil belajar, dan dokumentasi. Subjek penelitian ini adalah seluruh siswa kelas IVA SDN Kepatihan 05 Jember yang berjumlah 28 siswa. Hasil penelitian ini menunjukkan bahwa persentase aktivitas belajar siswa mengalami peningkatan. Pada siklus I menunjukkan hasil sebesar 56,29 persen dengan kriteria cukup, sedangkan pada siklus II sebesar 76,66 persen dengan kriteria baik. Rata-rata hasil belajar siswa juga mengalami peningkatan. Pada siklus I menunjukkan hasil sebesar 55,74 dengan kriteria cukup, sedangkan pada siklus II sebesar 75,71 dengan kriteria baik. Berdasarkan hasil penelitian, maka dapat disimpulkan bahwa penerapan teori belajar van Hiele dapat meningkatkan aktivitas dan hasil belajar siswa kelas IVA SDN Kepatihan 05 Jember.
\end{abstract}

Kata Kunci: teori van Hiele. Aktivitas belajar, hasil belajar.

\footnotetext{
Korespondensi :

${ }^{1)}$ Farisia Pratiwi Umami, Universitas Negeri Jember. Email: farisiamustafa97@ @mail.com

2) Titik Sugiarti, Universitas Negeri Jember

${ }^{3)}$ Fajar Surya Hutama, Universitas Negeri Jember
} 
PENDAHULUAN

Pendidikan dalam Undang- undang No.20 tahun 2003 tentang sistem Pendidikan Nasional pasal 1 (Kemendikbud) diartikan sebgai usaha sadar dan terencana untuk mewujudkan suasana belajar dan proses pembelajaran agar peserta didik secara aktif mengembangkan potensi dirinya untuk memiliki kekuatan spiritual keagamaan, akhlak mulia, pengendalian diri, kepribadian, kecerdasan, serta keterampilan yang diperlukan oleh dirinya, masyarakat, bangsa, dan negara.

Pendidikan sebagai usaha sadar, artinya bahwa tindakan yang dilakukan merupakan tindkan sengaja atau direncanakan dan bukan tindakan rifleks atau spontan yang tidak memiliki tujuan (Taufiq et al, 2010). Selain itu, tindakan ini harus mampu mengikutsertakan keterlibatan siswa secara aktif sehingga siswa dapat mengembangkan potensi yang dimilikinya. Dengan kata lain, pendidika bukanlah proses memaksakan kehendak orang dewasa (guru) kepada siswa, melainkan upaya menciptakan kondisi yang kondusif yang memberikan kesempatan kepada siswa untuk mengembangkan dirinya.

Pembelajaran matematika adalah suatu proses belajar mengajar yang dibangun oleh guru untuk mengembangkan kreativitas berpikir siswa yang dapat meningkatkan kemampuan berpikkir siswa, serta dapat meningkatkan kemampuan berpikir siswa, serta dapat meningkatkan kemampuan mengkonstruksi pengetahuan baru sebagai upaya meningkatkan penguasaan yang baik terhadap matematika (Susanto, 2013:186). Kegiatan pembelajaran terdiri dari kegiatan belajar dan mengajar. Kedua kegiatan tersebut akan berkolaborasi menjadi suatu kegiatan yang menimbulkan interaksi antara siswa dengan guru, siswa dengan siswa, dan siswa dengan lingkungannya.

Menurut Hutama

(2014:75), pendidikan di SD memegang peranan yang sangat penting dalam keberhasilan penidikan secara keseluruhan, sehingga semua pihak yang menjadi aktor dalam proses pembelajaran di SD harus benarbenar serius dalam menjalankan setiap perannya. Guru dan siswa sama-sama menjadi pelaku aktif untuk mencapai tujuan pembelajaran matematika.

Matematika merupakan ilmu pengetahuan yang diperoleh dengan bernalar, yaitu berfikir sistematis, logis, dan kritis dalam mengkomunikasikan gagasan atau pemecahan masalah (Depdiknas, 2006). Secara garis besar, 
matematika dibagi dalam 4 macam ilmu geometri, ilmu aritmatika, ilmu musika, dan ilmu astronomi. Salah satu pembelajaran dalam matematika adalah tentang geometri. Geometri merupakan ilmu pengetahuan dalam matematika yang mempelajari tentang bentuk-bentuk benda. Menurut Retnaning, Sugiarti, dan Yuliati (2013:1), geometri merupakan salah satu topik penting dalam matematika sekolah termasuk di SD (Sekolah Dasar) baik sebagai topik yang berdiri sendiri maupun sebagai pendukung topik yang lain. Tujuan pembelajaran geometri di SD agar siswa dapat menganalisis benda- benda geometri di lingkungannya

dan untuk meningkatkan hasil belajar siswa pada pembelajaran geometri.

Kondisi pendidikan yang ada pada suatu negara merupakan faktor yang mempengaruhi maju tidaknya suatu bangsa. Oleh karena itu, sering terjadi pembaharuan dalam bidang pendidikan yang merupakan salah satu bentuk upaya memperbaiki kualitas pendidikan yang merupakan salah satu bentuk upaya memperbaiki kualitas pendidikan. Salah satunya yaituu adanya pembaharuan metode pembelajaran yang ada di sekolah. Saat ini kurikulum yang digunakan untuk proses pembelajaran yaitu menggunakan kurikulum 2013, namun dalam pelaksanannya masih banyak guru yang dalam proses belajar dan mengajar masih menerapkan kurikulum lama yaitu KTSP 2006 terutama di SD. Pada umumnya metode pembelajaran yang digunakan di sekolah cenderung lebih berpusat pada guru. Metode tersebut masih banyak digunakan oleh guru terutama di SD, sehingga kurang memberdayakan siswa. Hal tersebut mengakibatkan rendahnya tingkat keberhasilan pada siswa khususnya pelajaran matematika.

Berdasarkan hasil wawancara dengan guru kelas IV di SDN Kepatihan 05 Jember pada tanggal 08 november 2018 diketahui bahwa pembelajaran matematika guru masih menggunakan metode ceramah. Saat pembelajaran matematika khususnya materi geometri, guru tidak memanfaatkan media yang ada dalam kelas. Guru lebih cenderung dengan menggunakan papan sebagai media pembelajaran.

Hutama (2014:75) menjelaskan bahwa salah satu usaha yang dapat dilakukan untuk menciptakan proses pendidikan yang berkualitas adalah melalui proses pembelajaran di sekolah. Seseorang yang berperan penting dalam meningkatkan kualitas pembelajaran adalah guru. Guru dapat menciptakan suatu pembelajaran yang ideal. 
Pembelajaran yang ideal adalah suatu pembelajaran yang

berkesinmabungan antara teori, model, metode, hingga media pembelajaran. Hal tersebut diharapkan dapat menjadikan pembelajaran lebih bermakna dan meningkatkan hasil belajar siswa. Salah satu upaya yang dapat

dilakukan oleh guru adalah dengan memilih teori belajar yang sesuai dengan materi yang diajarkan. Dari berbagai teori matematika yang ada salah satu teori belajar yangg cocok untuk mengajarkan materi geometri kepada siswa adalah teori belajar van Hiele.

Teori belajar van Hiele terdiri dari 5 fase (Sunardi, 2012:42), yaitu: (1) fase informasi; (2) orientasi terarah; (3) penjelasan; (4) orientasi bebas; dan (5) integrasi. Fase-fase dalam teori belajar van Hiele ini terdapat kegiatan-kegiatan yang dapat meningkatkan keaktifan siswa dalam proses pembelajaran. Menurut van Hiele (dalam Sunardi, 2015:204) terdapat lima tingkat pembelajaran geometri pada siswa yaitu tingkat 0 (visualisasi), tingkat 1 (analisis), tingkat 2 (deduksi informal), tingkat 3 (deduksi), dan tingkat 4 (rigor).

Hasil belajar matematika siswa kelas IVA SDN Kepatihan 05 Jember masih rendah. Hal ini terlihat dari nilai ulangan harian matematika siswa.
Terdapat 14 siswa dari 28 siswa yang nilainya $\leq 70$ yaitu siswa yang tidak memenuhi Kriteria Ketuntasan Minimum (KKM) SDN Kepatihan 05 Jember. Dari data tersebut, hasil belajar siswa kelas IVA perlu ditingkatkan.

Berdasarkan hasil observasi awal yang dilakukan saat pembelajaran matematika di kelas, guru memulai pembelajaran dengan langsung menjelaskan konsep. Menurut tahap-tahap teori pembelajaran van Hiele, kegiatan tersebut berada pada fase penjelasan. Setelah menjelaskan konsep, guru memberikan tugas individukepada siswa. Kegiatan pembelajaran tugas tersebut berada pada fase orientasi bebas. Dari hasil observasi tersebut, dapat disimpulkan bahwa pembelajaran matematika pada materi luas persegi, persegi panjang, dan segitiga di SDN Kepatihan 05 Jember tidak melalui fasefase dalam teori belajar van Hiele.

\section{METODE PENELITIAN}


Penelitian ini dilaksanakan di SDN Kepatihan 05 Jember. Subjek penelitian adalah seluruh siswa kelas IVA SDN Kepatihan 05 Jember tahun pelajaran 2018/2019 dengan jumlah siswa sebanyak 28 orang.

Jenis penelitian ini adalah penelitian tindakan kelas. Penelitian dilaksanakan sebanyak dua siklus. Setiap tindakan terdiri dari empat tahap meliputi: persencanaan, pelaksanaan, pengamatan, dan refleksi. Metode yang digunakan untuk mengumpulkan data adalah observasi, wawancara, tes hasil belajar, dan dokumentasi.

Aktivitas belajar yang diamati dalam penerapan teori belajar van Hiele yaitu: (1) mengamati bentuk bangun datar, menata kertas lipat, mengerjakan contoh soal luas persegi, persegi panjag, dan segitiga, mengerjakan tugas kelompok, membuat kesimpulan.

Hasil belajar yang dinilai dalam penelitian ini adalah hasil belajar kognitif pada jenjang kemampuan mengingat $(\mathrm{C} 1)$, memahami (C2), menerapkan (C3), dan menganalisa (C4) yang diperoleh dari kegiatan tes akhir siklus setelah menerapkan teori belajar van Hiele pada pokok bahasan luas persegi, persegi panjang, dan segitiga.

\section{HASIL DAN PEMBAHASAN}

Teori belajar van Hiele terdiri dari 5 fase (Sunardi, 2012:42), yaitu: (1) fase informasi; (2) orientasi terarah; (3) penjelasan; (4) orientasi bebas; dan (5) integrasi. Fase-fase dalam teori belajar van Hiele ini terdapat kegiatan-kegiatan yang dapat meningkatkan keaktifan siswa dalam proses pembelajaran. Menurut van Hiele (dalam Sunardi, 2015:204) terdapat lima tingkat pembelajaran geometri pada siswa yaitu tingkat 0 (visualisasi), tingkat 1 (analisis), tingkat 2 (deduksi informal), tingkat 3 (deduksi), dan tingkat 4 (rigor). Pengertian tingkat pembelajaran geometri tersebut sebagai berikut.

1. Tingkat 0 Visualisasi (pengenalan). Tingkat ini disebut tingkat pengenalan. Pada tngkat ini siswa sudah mengenal bentuk-bentuk geometri, misalnya persegi, persegi panjang, segitiga. Bentuk- bentuk geometri yang dikenal siswa sematamata didasarkan pada karakteristik visual atau penmapakan bentuknya scara keseluruhan, bukan sebagian dalam mengidentifikasi bangun. Mereka seringkali menggunakan prototipe visual. Sebagai contoh, mereka mengatakan bahwa bangunn yang diketahui adalah persegi panjang, karena seperti daun pintu. Sswa belum 
menyadari adanya sifat-sifat dari bangun geometri.

2. Tingkat 1 (analisis). Tingkat ini disebut juga dengan tingkat deskripsi. Ada tingkat ini siswa sudah mengenal sifatsifat bangun geometri yang didasarkan pada analisis informal tentang bagianbagian bangun dan atribut- atribut komponennya. Pada tingkat ini mulai banyak adanya analisis terhadap konsep-konsep geometri. Siswa dapat mengenali dan menentukan karakteristik bangun berdasarkan sifatsifatnya. Melalui pengamatan, eksperimen, mengukur, menggambar, dan membuat model. Siswa dapat mengenali dan membedakan karakteristik suatu bangun. Siswa melihat bahwa suatu bangun mempunyai bagian-bagian tertentu yang dapat dikenali. Namun demikian siswa belum sepenuhnya dapat menjelaskan hubungan antara sifat yang satu dengan sifat yang lain, siswa sama sekali belum bisa melihat hubungan antara beberapa bangun, dan definisi abstrak belum atau tidak dapat dimengerti. Suatu contoh, siswa belum bisa menyatakan bahwa persegi panjang juga merupakan jajar genjang.

3. Tingkat 2 Deduksi informal (pengurutan). Tingkat ini sering disebut dengan tingkat abstraksi atau tingkat pengurutan. Pada tingkat ini siswa dapat melihat hubungan antara sifatsifat dalam satu bangun misal, dalam belah ketupat sisi yang berhadapan sejajar mengharuskan sudut-sudut yang berhadapan sama besar. Siswa juga dapat melihat hubungan sifat di antara beberapa bangun. Suatu contoh, belah ketupat adalah jajar genjang karena sifat-sifat jajar genjang juga dimiliki oleh belah ketupat. Siswa dapat mengurutkan secara logis sifat-sifat bangun. Misalnya, siswa menyatakan bahwa persegi juga merupakan belah ketupat dan belah ketupat juga merupakan jajar genjang. Siswa dapat menyusun definisi dan menemukan sifat-sifat bangun melalui induktif (deduksi informal). Definisi yang dibangun tidak hanya berbentuk deskripsi tetapi merupakan hasil dari pengaturan secara logis dari sifat- sifat konsep yang didefinisikan. Sebagai contoh, siswa dapat menunjukkan bahwa jumlah ukuran sudut-sudut segiempat adalah 3600 sebab setiap segiempat dapat didekomposisi menjadi dua segitiga yang masingmasing 1800, tetapi siswa tidak bisa menjelaskan secara deduktif. 
4. Tingkat 3 (Deduksi). Pada tingkat ini berpikir deduktif siswa sudah mulai berkembang dan penalaran deduksi sebagai cara untuk membangun dalam sistem aksiomatik telah dipahami. Hal ini telah ditunjukkan siswa dengan membuktikan suatu pernyataan tentang geometri menggunakan alasan yang logis dan deduktif. Suatu contoh, siswa telah dapat menyusun bukti jika sisisisi berhadapan suatu segiempat saling sejajar, maka sudut-sudut yang berhadapan sama besar. Struktur deduktif aksiomatik yang lengkap dengan pengertian pangkal, postulat/aksioma, definisi, teorema, dan akibat yang secara implisit ada pada tingkat deduksi informal, menjadi objek yang eksplisit dalam pemikiran siswa pada tingkat ini. Siswa telah dapat mengembangkan bukti lebih dari satu cara. Timbal balik antara syarat perlu dan cukup dipahami. Pada tingkat ini siswa belum mengerti mengapa sesuatu itu dijadikan teorema, aksioma atau definisi.

5. Tingkat 4 (Rigor). Dalam tingkat siswa dapat bekerja dalam berbagai struktur deduksi aksiomatik. Siswa dapat menemukan perbedaan di antara dua struktur. Siswa memahami perbedaan di antara geometri Euclides dan nonEuclides. Geometri Euclides merupakan geometri yang telah ditemukan setelah Euclides, sedangkan geometri nin-Euclides adalah geometri yang ditemukan setelah geometri Euclides. Pada tahap ini, postulat, aksioma, definisi dan teorema menjadi objek pemikirannya.

Berdasarkan hasil penelian, di dapatkan presentase Aktivitas Belajar Siswa yang berdasarkan indikator penelitian, dapat dilihat pada Gambar 1 


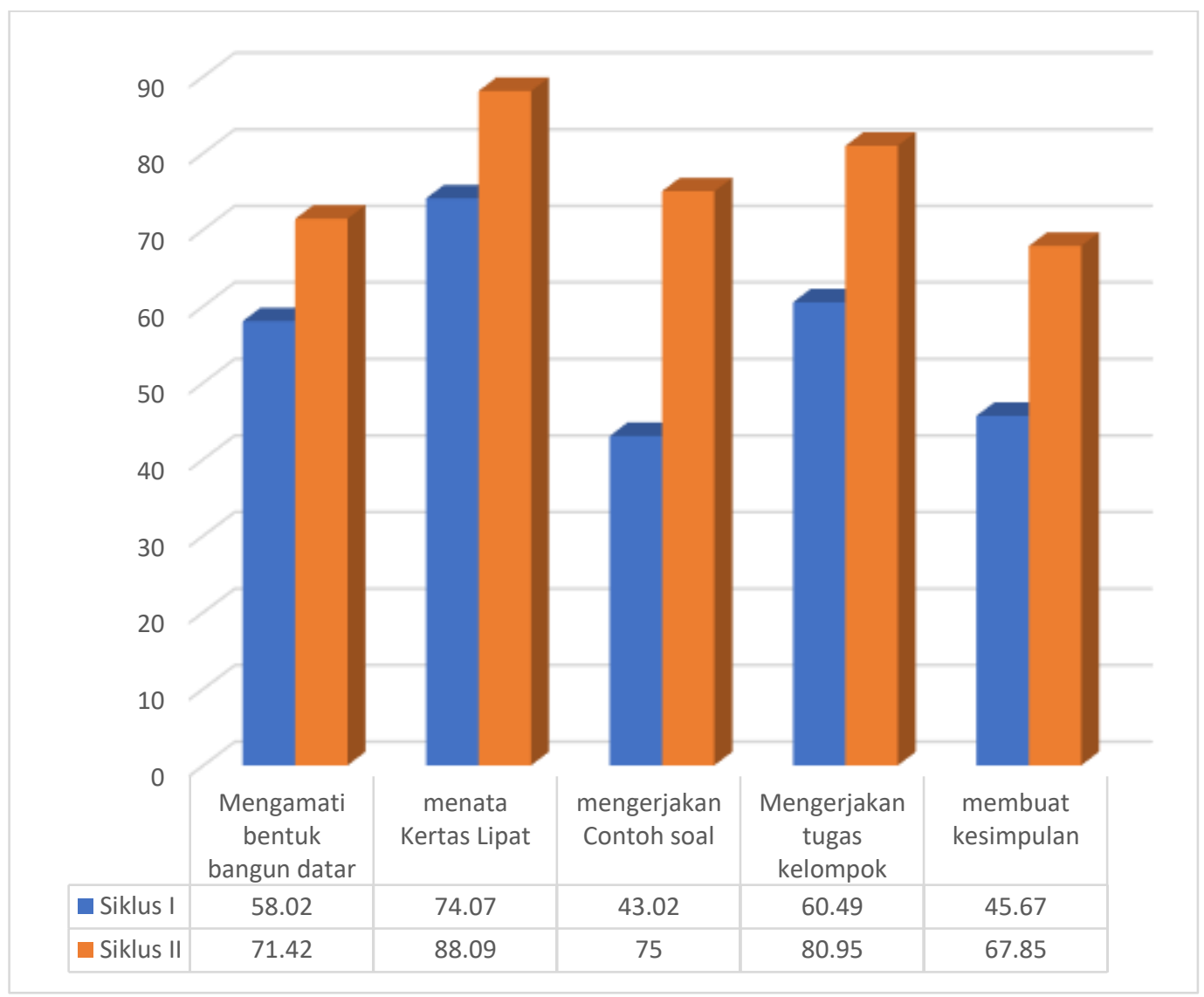

Gambar 1. Grafik Aktivitas Belajar Siswa tiap Aktivitas pada Siklus I dan II

Berdasarkan peningkatan aktivitas siswa pada tiap aktivitas membuat ratarata aktivitas belajar siswa mengalami peningkatan. Persentase aktivitas belajar siswa pada siklus I sebesar 56,29\%, sedangkan pada siklus II sebesar 76,66\%.
Setelah diperoleh penilaian aktivitas belajar siswa, maka selanjutnya dilakukan penilaian hasil belajar pada tiap siklus yaitu siklus I dan siklus II. Hasil belajar siswa setiap kriteria juga meningkat. Peningkatan tersebut dapat dilihat gambar berikut. 


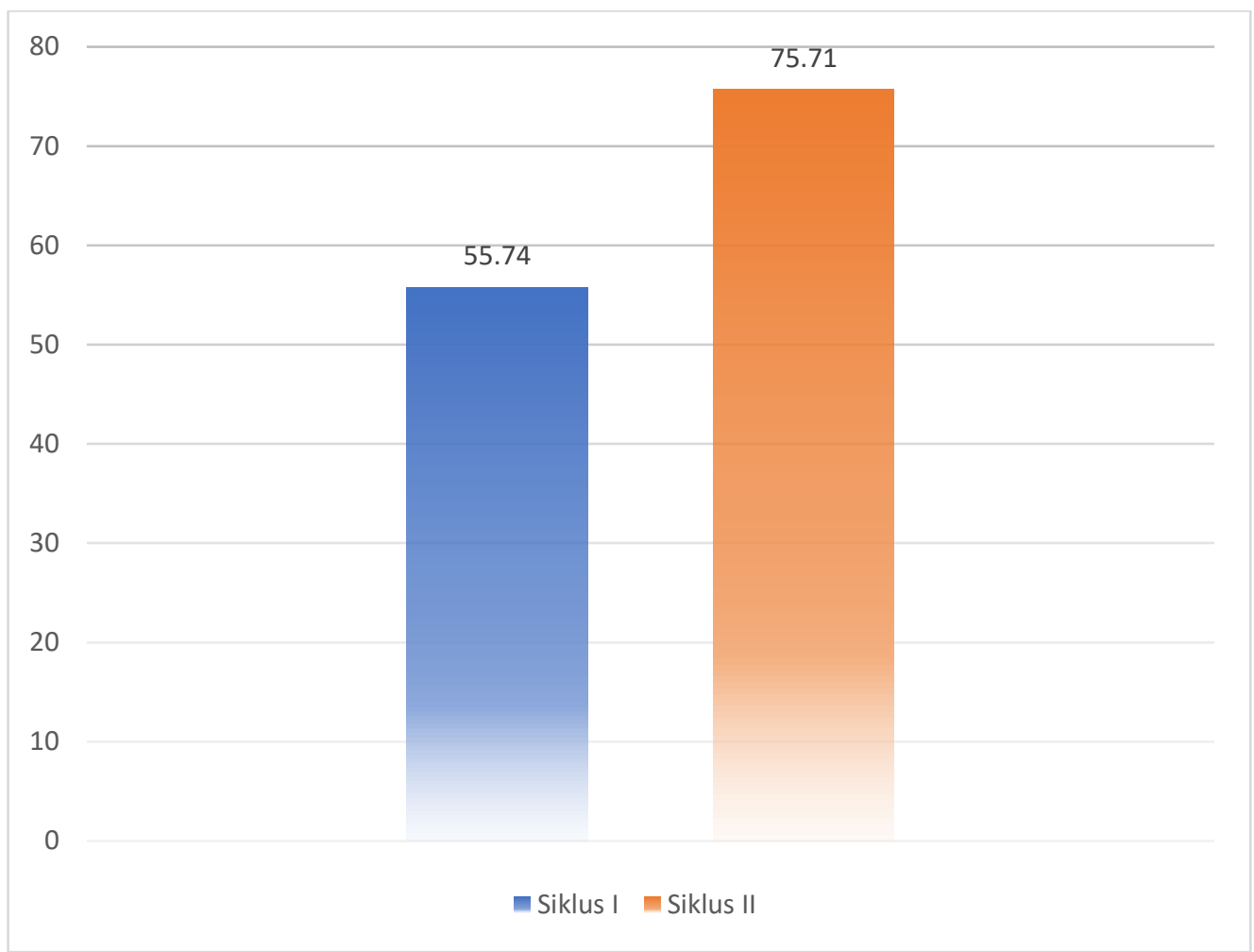

Gambar 2. Grafik perbandingan siklus I dan siklus II

Setelah diterapkannya teori belajar van Hiele pada pembelajaran matematika pokok bahasan luas persegi, persegi panjang, dan segitiga, mengalami peningkatan.

Hasil belajar siswa pada siklus I yaitu 55,74. Hasil belajar pada siklus II sebesar 75,71 .

\section{SIMPULAN DAN SARAN}

\section{Simpulan}

Berdasarkan penerapan teori belajar van Hiele yang dilaksanakan selama dua siklus pada siswa kelas IVA SDN Kepatihan 05 Jember dapat disimpulkan sebagai berikut.
1. Penerapan teori belajar van Hiele dalam pembelajaran matematika dilaksanakan sesuai dengan fase-fase teori van Hiele, yaitu fase informasi, orientasi terarah, penegasan, orientasi bebas, dan integrasi. Dari lima fase tersebut, fase integrasi adalah fase yang paling sulit diterapkan karena siswa malu untuk mempresentasikan hasil dari tugas kelompok sehingga guru harus memilih salah satu perwakilan kelompok untuk ke depan kelas mempresentasikan hasil kerjanya, sedangkan fase orientasi terarah adalah fase dimana siswa sangat aktif dalam pembelajaran karena siswa dapat belajar sambil 
bermain media yang tersedia dan dapat terlaksana dengan lancar.

2. Penerapan teori belajar van Hiele pada pembelajaran matematika pook bahasan luas persegi, persegi panjang dan segitiga di kelas IVA SDN Kepatihan 05 Jember tahun pelajaran 2018/2019 mengalami peningkatan. Persentase rata-rata aktivitas belajar siswa mengalami peningkatan pada siklus I sebesar $56,29 \%$ dengan kriteria cukup dan pada siklus II meningkat menjadi $76,66 \%$ dengan kriteria baik.

3. Penerapan teori belajar van Hiele pada pembelajaran matematika pokok bahasan luas persegi, persegi panjang dan segitiga di kelas IVA SDN Kepatihan 05 Jember tahun pelajaran 2018/2019 mengalami peningkatan. Rata-rata hasil belajar siswa pada siklus I sebesar 55,74 dengan kriteria cukup meningkat menjadi 76,66 pada siklus II dengan kriteria baik.

\section{Saran}

Saran yang perlu dipertimbangkan untuk penerapan teori belajar van Hiele dalam meningkatkan aktivitas dan hasil belajar siswa pada pokok bahasan luas persegi, persegi panjang, dan segitiga, yaitu (a) Bagi guru, agar dapat melanjutkan dan memaksimalkan penerapan teori belajar van Hiele untuk materi selanjutnya agar aktivitas dan hasil belajar siswa lebih meningkat, serta level pemahaman geometri siswa dapat meningkat. Guru sebaiknya memberikan lebih banyak pertanyaanpertanyaan yang dapat menggali pemahaman awal siswa pada fase informasi. (b) Bagi siswa, dengan adanya penelitian ini membuat siswa lebih aktif dan tidak cepat bosan selama proses pembelajaran. Peningkatan aktivitas dan hasil belajar dengan menerapkan teori belajar van Hiele dapat tercapai dengan baik jika siswa mampu berperan aktif dalam belajar bersama. (c) Bagi peneliti lain, melalui hasil penelitian penerapan teori belajar van Hiele diharapkan dapat dijadikan referensi dalam melakukan penelitian selanjutnya, dan lebih baik lagi dalam menerapkan fase-fase teori belajar van Hiele khususnya pada fase informasi dimana dalam penelitian ini guru kurang maksimal dalam memberikan contoh materi bangun datar. 


\section{DAFTAR PUSTAKA}

Depdiknas. 2006. Standar Isi SD. Jakarta: Depdiknas.

Diasti, L. C. 2017. Penerapan Model Pembelajaran Van Hiele untuk Meningkatkan Aktivitas dan Hasil Belajar Pokok Bahasan Luas Trapesium dan Layang-layang Siswa Kelas VA SDN Maesan. Tidak diterbitkan. Skripsi. Jember: Universitas Jember. https://bit.ly/2XtmKLS. [Diakses pada 19 September 2018].

Hutama, F. S. 2014. Pengaruh Model PBL melalui Pendekatan CTL terhadap Hasil Belajar IPS. Jurnal Pendidikan Humaniora. 2(1): 75-83. https://jurnal.unej.ac.id. [Diakses pada 8 Agustus 2018].

Retnaning, O., T. Sugiarti, dan N. Yuliati. 2013. Analisis Penyajian Pembelajaran Geometri pada Buku Sekolah Elektronik (BSE) SD berdasarkan Teori Van Hiele. http://repository.unej.ac.id. [Diakses pada 8 Agustus 2018].

Sunardi. 2012. Strategi Belajar Mengajar Matematika. Universitas Jember.

Susanto, A. 2013. Teori Belajar dan Pembelajaran di Sekolah Dasar. Jakarta: Kencana Media Grup.

Undang-undang Republik Indonesia Nomor 20 Tahun 2003. Sistem Pendidikan Nasional. 8 Juli 2003. Lembaran Negara Republik Indonesia Tahun 2003 Nomor 4301. Jakarta. 